\title{
Pharmacogenomic considerations in opioid analgesia
}

\author{
Pascal H Vuilleumier' \\ Ulrike M Stamer' \\ Ruth Landau ${ }^{2}$ \\ 'Klinik für Anästhesiologie und \\ Schmerztherapie, Inselspital \\ Universität Bern, Switzerland; \\ ${ }^{2}$ Department of Anesthesiology \\ and Pain Medicine, University of \\ Washington School of Medicine, \\ Seattle, WA, USA
}

This article was published in the following Dove Press journal:

Pharmacogenomics and Personalized Medicine

22 August 2012

Number of times this article has been viewed

\begin{abstract}
Translating pharmacogenetics to clinical practice has been particularly challenging in the context of pain, due to the complexity of this multifaceted phenotype and the overall subjective nature of pain perception and response to analgesia. Overall, numerous genes involved with the pharmacokinetics and dynamics of opioids response are candidate genes in the context of opioid analgesia. The clinical relevance of CYP2D6 genotyping to predict analgesic outcomes is still relatively unknown; the two extremes in CYP2D6 genotype (ultrarapid and poor metabolism) seem to predict pain response and/or adverse effects. Overall, the level of evidence linking genetic variability (CYP2D6 and CYP3A4) to oxycodone response and phenotype (altered biotransformation of oxycodone into oxymorphone and overall clearance of oxycodone and oxymorphone) is strong; however, there has been no randomized clinical trial on the benefits of genetic testing prior to oxycodone therapy. On the other hand, predicting the analgesic response to morphine based on pharmacogenetic testing is more complex; though there was hope that simple genetic testing would allow tailoring morphine doses to provide optimal analgesia, this is unlikely to occur. A variety of polymorphisms clearly influence pain perception and behavior in response to pain. However, the response to analgesics also differs depending on the pain modality and the potential for repeated noxious stimuli, the opioid prescribed, and even its route of administration.
\end{abstract}

Keywords: pain perception, opioid analgesia, genetic variation, pharmacogenetics

\section{Introduction}

Recent developments in genomic research have opened vast opportunities to expand and improve our understanding of how genetic variability affects response to prescribed medication. The ultimate goal of pharmacogenomic research is to offer "tailored personalized medicine" to improve the efficacy of medication as well as patient safety by helping predict the risk of adverse outcomes. Although numerous hurdles have limited the creation and implementation of pharmacogenetic testing, several pharmacogenetic tests have been recently developed, ${ }^{1}$ and the US Food and Drug Administration (FDA) ${ }^{2}$ and the European Medicines Agency have approved several drug label modifications to contain pharmacogenetic information. ${ }^{3}$ Furthermore, in the last year, the Clinical Pharmacogenetics Implementation Consortium ${ }^{4}$ has published guidelines for warfarin, ${ }^{5}$ clopidogrel, ${ }^{6}$ and thiopurine dosing ${ }^{7}$ based on pharmacogenetic testing, and the guidelines for codeine therapy in the context of CYP2D6 genotype are being published these days. ${ }^{8}$

Pain perception is one of the most complex quantifiable traits because it encompasses several phenotypes involving the peripheral and central nervous systems, 
and as a complex trait it is expected to have a polygenic nature shaped by environmental factors such as trauma, lifestyle, and stress. In addition, an important characteristic in determining the pain phenotype is the wide interindividual pharmacologic range in response to drugs. Therefore, not surprisingly, translating pharmacogenetics to clinical practice has been particularly challenging in the context of pain, due to the complexity of this multifaceted phenotype and the overall subjective nature of pain perception and response to analgesia. Yet with a growing body of evidence demonstrating a strong association between severe acute pain and the risk for persistent pain, identifying individuals with an increased vulnerability to pain, including genetic factors, may allow to substantially improve clinical outcomes. ${ }^{9}$ This overview will present an outline of some genetic variants involved in pain and analgesic responses, bearing in mind the interplay between pharmacokinetic (eg, the CYP450 family of enzymes ${ }^{10}$ ) and pharmacodynamic (eg, the well-studied $\mu$-opioid receptor) effects. It will review patient-specific considerations in the clinical setting of opioids for acute pain, including postoperative pain, opioids for labor analgesia, and the response to opioids for chronic pain. Finally, the clinical utility of pharmacogenomic testing in pain management and the future of personalized medicine in this context will be reviewed.

\section{Interindividual variability in pain sensitivity}

Clinicians and pain providers are well aware of the large and unpredictable interindividual variability in pain perception and sensitivity to analgesia. ${ }^{11,12}$ Twin and volunteer studies have demonstrated a significant heritability for experimental pain responses, ${ }^{13,14}$ and recent genomic and pharmacogenetic research has considered numerous candidate genes as suitable targets for the study of the genetic and inheritable basis of pain and/or response to analgesic drugs. ${ }^{15}$

The "genetic architecture of human pain perception" has been proposed to include rare deleterious genetic variants and more common genetic polymorphisms as mediators of human pain perception and clinical pain phenotypes. ${ }^{16}$ An extremely rare pain phenotype characterized by a total absence of pain perception ("congenital insensitivity to pain") with no associated neuropathy has been associated with the mutations in the gene $S C N 9 A$, encoding the $\alpha$-subunit of the voltage-gated sodium channel NaV1.7. ${ }^{17,18}$ This discovery has already opened directions for novel generations of therapeutic agents blocking $\mathrm{NaV} 1.7,{ }^{19,20}$ with the hope that these drugs may provide selective and safe analgesia/anesthesia.
Another clinical phenotype resulting from loss-of-function mutations of NaV1.7 termed "congenital indifference to pain," refers to individuals who actually recognize painful stimuli but lack the affective-motivational component of pain perception, do not show withdrawal responses, and often die in childhood. ${ }^{21}$ Along the same line, it has also been proposed from an evolutionary standpoint that individuals experiencing severe pain may in fact not be disfavored, as they are likely to have an increased capacity to sense essentially all environmental stimuli and increase their ability to detect and avoid environmental threats. With that in mind, lower pain threshold is commonly associated with the ability to detect a wide variety of nonnoxious sensory stimuli, and may represent a beneficial adaptive mechanism. This has been suggested as an explanation for sex-dependent differences in pain sensitivity, resulting from evolutionary pain-modulation processes, which afford women a greater sense of awareness of potential environmental threats to offer heightened protection to their offspring. ${ }^{22}$

In the era of opioid therapy, pharmacogenomic studies to guide opioid-based analgesic regimens are flourishing. Among the numerous candidate genes that have been considered important in opioid response, the CYP family of enzymes, the $\mu$-opioid receptor gene (OPRM1, p.118 A/G), the catechol- $O$-methyltransferase gene (COMT, Val158Met), several variants of the ATP-binding cassette, and subfamily $\mathrm{B}$ member 1 gene $(A B C B 1)$ have been extensively reviewed. However, most drug effects are determined by the interaction of several polymorphisms that influence the pharmacokinetics and pharmacodynamics of medications, including inherited differences in drug targets (eg, receptors) and drug disposition (eg, drug-metabolizing enzymes and transporters). This interplay may result in polygenic determinants that involve numerous potential combinations of drugmetabolism, drug-transporters and drug-receptor genotypes with corresponding drug-response phenotypes yielding a wide-range of therapeutic indexes (efficacy/toxicity ratios) for a given drug.

\section{Genetic variants of CYP family of enzymes and opioid metabolism}

Altogether, $20 \%-25 \%$ of clinically used drugs are influenced by genetic variants of enzymes. ${ }^{23}$ Cytochrome $\mathrm{P} 450$ enzymes (CYPs) play a major role, as these are responsible for about $80 \%$ of phase I metabolism. ${ }^{24} \mathrm{CYP} 2 \mathrm{D} 6$ metabolizes approximately $25 \%$ of frequently used drugs, eg, $\beta$-blockers, antiarrhythmics, antidepressants, neuroleptics, and analgesics. ${ }^{25,26}$ Four metabolic phenotypes are characterized; poor (PM), 
intermediate (IM), extensive (EM), and ultrarapid (UM) metabolizers. Critical base changes or deletions result in more than 80 distinct CYP2D6 allelic variants, explaining the wide spectrum of metabolic diversity within populations. ${ }^{27}$ A comprehensive list of all known cytochrome alleles is displayed at the website of the CYP Allele Nomenclature Committee (http://www.imm.ki.se/CYPalleles). Relevant polymorphisms resulting in nonfunctional alleles are single base exchanges (CYP2D6*4 [rs3892097], CYP2D6*7 [rs5030867], CYP2D6*8 [rs5030865]) or deletions (CYP2D6*3 [rs35742686], CYP2D6*6 [rs5030655]) within the cytochrome P450 2D6 gene locus. Deletion of the entire CYP2D6 gene (CYP2D6*5) also results in the absence of CYP2D6 protein production. Subjects with these homozygous PM-associated variants are at increased risk for potentially severe adverse side effects due to drug concentrations exceeding the therapeutic level (ie, tricyclic antidepressants, antiarrhythmics) or for therapeutic failure due to poor metabolism of a prodrug (ie, codeine, tramadol) into its active metabolite. In contrast, duplication or multiduplication of the CYP2D6 gene is related to the UM phenotype and increased enzyme activity resulting in rapid decline of respective plasmatic drug concentrations. Thus, therapeutic effects cannot be obtained in UM at conventional doses of an active drug. ${ }^{28}$

The distribution of different CYP2D6 phenotypes within specific cohorts varies depending on geographic region and individuals' ethnicity; ${ }^{13}$ up to $7 \%-10 \%$ of Caucasians are categorized as PMs. In a study screening 1060 individuals within 52 worldwide-distributed populations,${ }^{29}$ a greater variation of CYP2D6 within populations than between groups thereof was found. When comparing allelic distribution among different ethnicities, the CYP2D6*4 allele is frequently found in Caucasians (in the order of $20 \%$ allelic frequency) and represents more than $75 \%$ of the mutant CYP2D6 alleles, while it is extremely rare among Chinese individuals. Other alleles such as the CYP2D $6^{*} 10$, resulting in an IM phenotype, are particularly frequent among Asian individuals, and so are the $C Y P 2 D 6^{*} 45$ and $C Y P 2 D 6^{*} 46$ alleles among individuals of black African origin. In a middle European population, $3 \%-5 \%$ are UMs, whereas in Scandinavia this figure decreases to $1 \%-2 \%$; however, it increases for subjects from the Mediterranean (10\%-12\%), Saudi Arabia (21\%) and Ethiopia (29\%). ${ }^{23}$ Of particular clinical relevance, the UM phenotype is the second most common type in North Africa, the Middle East, Oceania, and the EMs being the most common. Prodrugs that rely on CPY2D6 metabolism are likely to reach higher-than-expected plasmatic concentrations of their active metabolite in UMs. Conversely, $7 \%-10 \%$ of Caucasians, those carrying the PM phenotype, are at risk for higher-than-expected drug plasma concentrations of a parent drug, because of delayed or absent CYP2D6 metabolism.

The varied and unpredictable analgesic profiles of codeine, dihydrocodeine, hydrocodone, oxycodone, and tramadol are predominantly explained by CYP2D6 and CYP3A4 metabolism. In recent years, there have been several reports associating CYP2D6 genotypes and near misses or fatal outcomes after opioid use. ${ }^{30-33}$ Adding to the complexity of the metabolic pathway of one drug, adverse outcomes have been noted as a result of multiple drug therapies interacting at the same $\mathrm{CYP}^{34}$

\section{Codeine}

Codeine is a prodrug with a low affinity and low intrinsic activity at the $\mu$-opioid receptor (200 times and 50 times less than morphine, respectively). ${ }^{35}$ It is classified as a weak opioid (World Health Organization class II), as it is a less potent $\mu$-opioid receptor agonist than morphine. Codeine was initially prescribed because of the belief that this weak opioid is safe and would not result in adverse outcomes. For that reason, codeine has been considered a safe alternative to other opioids for outpatient pain management, and is still available in some countries as an over-the-counter medication, either alone or in combination with paracetamol (acetaminophen). Current use of codeine includes pediatric patients ${ }^{36}$ and treatment of postoperative pain, although largescale evidence on efficacy is sparse and has been challenged by a recent meta-analysis. ${ }^{37}$

Codeine is a prodrug, and requires $O$-demethylation catalyzed by CYP2D6 to be converted into morphine and become analgesic; this metabolic pathway accounts for $10 \%$ of codeine clearance (Figure 1). The conversion of codeine into norcodeine by CYP3A4 and into codeine-6-glucuronide by glucuronidation represents approximately $80 \%$ of codeine clearance. Morphine is further metabolized into morphine6-glucuronide (M6G) and morphine-3-glucuronide; both morphine and M6G display opioid activity.

The clinical relevance of CYP2D6 genotyping to predict analgesic outcomes is still relatively unknown. In a recent pilot study, the relationship between CYP2D6 genotype, postcesarean pain scores, codeine consumption, and side effects were evaluated. ${ }^{38}$ The two extremes in CYP2D6 genotype seemed to predict pain response and/or adverse effects.

Individuals with an UM phenotype carry a risk for respiratory depression with codeine, particularly if CYP3A4 activity is inhibited by concomitant use of antibiotics or in 


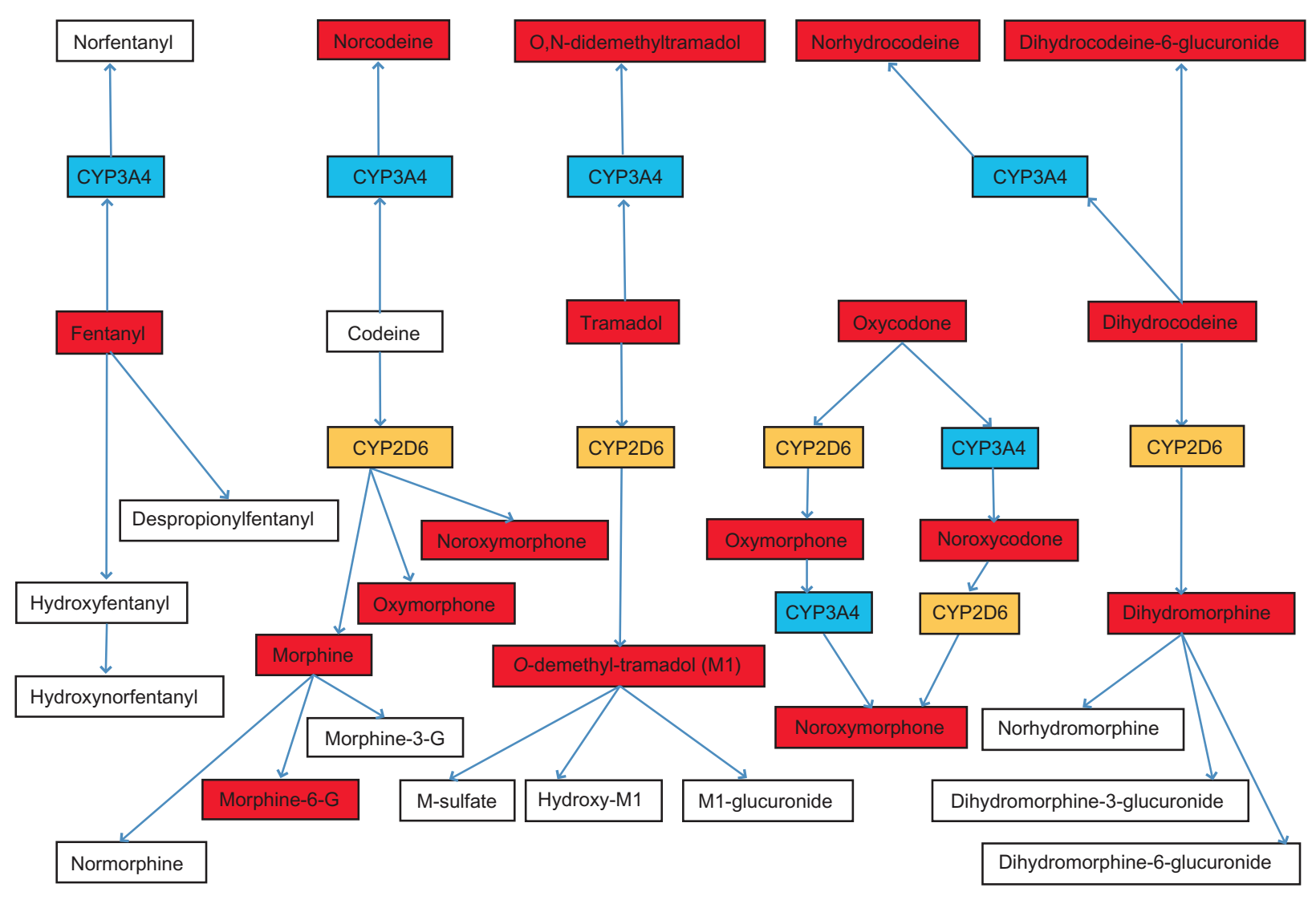

Figure I CYP metabolism involved in opioid clearance.

the context of kidney dysfunction. ${ }^{30}$ Several reports of fatalities after codeine prescription in pediatric cases with UM have been published in recent years: a 2-year-old boy died due to codeine overdose after a minor surgical procedure, ${ }^{39}$ and a 29-month-old child of North African descent suffered major hypoxic brain injury following a dose of acetaminophen and codeine 2 days after an uneventful anesthetic for tonsillectomy ${ }^{40}$ By account of ethnic affiliation, the risk of this child of carrying a CYP2D6 gene duplication is increased about threefold compared to Caucasian subjects. ${ }^{40}$

Perhaps the most striking report is that of the death of a breast-fed 13-day-old neonate following a morphine overdose because his mother was taking codeine after childbirth. This resulted in a recent FDA warning on codeine use in nursing mothers. ${ }^{41}$ Toxic blood levels of morphine or its active metabolite M6G may arise in mothers and neonates that are CYP2D6 ultrarapid or extensive metabolizers. The mother was categorized as a CYP2D6 ultrarapid metabolizer and her breast milk had a morphine concentration of $87 \mathrm{ng} / \mathrm{mL}$, the typical range being $1.9-20.5 \mathrm{ng} / \mathrm{mL}$ at doses of $60 \mathrm{mg}$ codeine every 6 hours. The infant was categorized as a CYP2D6 extensive metabolizer (extensively metabolizing the prodrug codeine to morphine), and postmortem toxicology tests using gas-chromatography mass spectrometry revealed blood concentrations of morphine at $70 \mathrm{ng} / \mathrm{mL}$. Sixty $\mathrm{mg}$ codeine/day for treatment of postpartum pain normally results in maximum morphine plasma concentrations of $2.2 \mathrm{ng} / \mathrm{mL}$ in breast-fed neonates..$^{42}$ In contrast, neonates prescribed morphine for analgesia displayed serum morphine concentrations of $10-12 \mathrm{ng} / \mathrm{mL}{ }^{43}$ In a quantitative modeling study simulating the risk for neonates according to CYP2D6 genotypes, repeated codeine administration in a breast-feeding mother demonstrated that toxic plasma levels of morphine could be reached in 4 days. ${ }^{44}$ The authors concluded that unmonitored use of codeine for postlabor pain in breast-feeding mothers should not be considered a safe practice.

Codeine and morphine clearance in breast-feeding mothers and their relation to CYP2D6 genotypes have been extensively commented on and evaluated. ${ }^{43,45-47}$ Since 2007, the FDA has required manufacturers of prescription codeine products to state in the "Precautions" section of the drug label the risks of prescribing codeine to breast-feeding mothers. ${ }^{48}$

An FDA-approved genetic test (AmpliChip CYP450: Roche Diagnostics, Palo Alto, CA) is commercially available to test genetic variants of CYP2D6. ${ }^{49}$ Overall, the level of 
evidence linking gene variation ( $C Y P 2 D 6)$ to phenotype (increased biotransformation of codeine into morphine) is significant; however, there is no randomized clinical trial assessing the benefits of genetic testing prior to codeine therapy at large. In addition, while insufficient morphine formation from codeine resulting in failure of analgesia can currently be well predicted, extremely high morphine formation still requires the effort of combining genotyping with phenotyping. ${ }^{50}$ Finally, the Clinical Pharmacogenetics Implementation Consortium has just published guidelines based on a focused review and interpretation of the literature by experts in the field (Table 1). ${ }^{8}$

\section{Dihydrocodeine}

Dihydrocodeine, a semisynthetic opioid, undergoes similar metabolic pathways as its analog codeine. CYP2D6 catalyses $O$-demethylation to dihydromorphine, an active metabolite with an opioid receptor activity comparable to that of morphine. CYP3A4 catalyzes $N$-demethylation to nordihydrocodeine and nordihydromorphine. ${ }^{26}$ Studies to evaluate CYP2D6 metabolism utilize quinidine to inhibit CYP2D6 metabolism, thus resulting in a PM phenotype; plasma concentrations of dihydromorphine were reduced three- to fourfold, and urinary excretion of dihydromorphine was decreased from $0.91 \%$ to $0.28 \%$ in the first 12 hours in quinidine-induced poor metabolizers. ${ }^{51}$ Pain thresholds, however, were not different after a single dose of dihydrocodeine along with quinidine, suggesting that this metabolic pathway and biotransformation of dihydrocodeine into dihydromorphine may not be clinically important for analgesia. ${ }^{51,52}$

\section{Hydrocodone}

Hydrocodone is a synthetic opioid analog to dihydrocodeine. The production of the active metabolite hydromorphone from hydrocodone is reduced in CYP2D6 PMs. ${ }^{53}$ In vitro studies show that the $O$-demethylation of hydrocodone is predominantly catalyzed by CYP2D6 and to a lesser extent by an unknown low-affinity cytochrome P450 enzyme. ${ }^{54}$ Norhydrocodone formation is attributed in part to CYP3A4, and approximately $40 \%$ of the clearance of hydrocodone is via non-CYP pathways. In a volunteer trial, CYP2D6 EMs and PMs were equally responsive to oral hydrocodone, and quinidine had no consistent effect on their responses, even though quinidine abolished the preexisting metabolic differences in hydromorphone production, as measured in urine. ${ }^{55}$

A recent case-report of a fatal hydrocodone overdose in a child demonstrated the effect of CYP2D6 genotype on hydrocodone clearance and highlights the complex interplay between pharmacogenetic factors and drug-drug interactions. ${ }^{56}$ The child had a PM CYP2D6 phenotype and was treated with clarithromycin, a potent inhibitor of CYP3A4, for an ear infection. The concomitant medication resulted in a substantial reduction in hydrocodone clearance. The combination of reduced clearance with an inhibited CYP3A4 and a PM phenotype contributed to this fatal overdose. Overall, data regarding pain management and hydrocodone is sparse, and there is no recommendation for pharmacogenetic testing to improve hydrocodone's efficacy and safety profile.

\section{Tramadol}

Tramadol, a synthetic analog of codeine and morphine, consists of two enantiomers, both of which contribute to analgesic activity via different mechanisms. (+)-Tramadol and the main metabolite (+)-O-demethyl-tramadol (M1) are agonists of the $\mu$-opioid receptor. (+)- $O$-demethyl-tramadol's affinity for $\mu$-opioid receptors is approximately 200 times greater

Table I Codeine therapy recommendations based on CYP2D6 phenotype

\begin{tabular}{|c|c|c|c|}
\hline Phenotype & $\begin{array}{l}\text { Implications for } \\
\text { codeine metabolism }\end{array}$ & $\begin{array}{l}\text { Recommendations } \\
\text { for codeine therapy }\end{array}$ & $\begin{array}{l}\text { Classification of recommendation } \\
\text { for codeine therapy }\end{array}$ \\
\hline $\begin{array}{l}\text { Ultrapid metabolized } \\
\text { (CYP2D6 activity score }>2 \text { ) }\end{array}$ & $\begin{array}{l}\text { Increased morphine } \\
\text { formation } \\
\text { Higher risk of morphine } \\
\text { toxicity }\end{array}$ & $\begin{array}{l}\text { Avoid codeine use (potential for toxicity) } \\
\text { Consider alternative such as morphine } \\
\text { or a non-opioid } \\
\text { Consider avoiding tramadol }\end{array}$ & Strong \\
\hline $\begin{array}{l}\text { Extensive metabolizer } \\
(\text { CYP2D6 activity score }=1-2)\end{array}$ & $\begin{array}{l}\text { Normal morphine } \\
\text { formation }\end{array}$ & $\begin{array}{l}\text { I5-60 mg every } 4 \text { th as needed for pain } \\
\text { (label recommendation) }\end{array}$ & Strong \\
\hline $\begin{array}{l}\text { Intermediate metabolizer } \\
(\text { CYP2D6 activity score }=0.5)\end{array}$ & $\begin{array}{l}\text { Reduced morphine } \\
\text { formation }\end{array}$ & $\begin{array}{l}\text { Start at } 15-60 \mathrm{mg} \text { every } 4 \text { th as needed for pain } \\
\text { If no response, consider alternative analgesics } \\
\text { Monitor tramadol use for response }\end{array}$ & Moderate \\
\hline $\begin{array}{l}\text { Poor metabolizer } \\
(\text { CYP2D6 activity score }=0)\end{array}$ & $\begin{array}{l}\text { Greatly reduced morphine } \\
\text { formation } \\
\text { Insufficient pain relief }\end{array}$ & $\begin{array}{l}\text { Avoid codeine use (lack of efficacy) } \\
\text { Consider alternative such as morphine or } \\
\text { a non-opioid. Consider avoiding tramadol }\end{array}$ & Strong \\
\hline
\end{tabular}

Adapted from the Clinical Pharmacogenetics Implementation Consortium (CPIC) Guideliness for Codeine Therapy in the Context of Cytochrome P450 2D6 (CYP2D6) Genotype. ${ }^{8}$ 
than that of the parent compound.$^{57}(+)$-O-demethyl-tramadol is metabolized by CYP2D6, therefore the CYP2D6 genotype will influence the response to tramadol. ${ }^{58-65}(+)$-Tramadol inhibits serotonin reuptake and (-)-tramadol inhibits norepinephrine reuptake, enhancing inhibitory effects on pain transmission in the spinal cord.

Clinical studies have demonstrated that response rates to tramadol are significantly lower in PM compared to EM individuals. ${ }^{63}$ In a postoperative study evaluating the efficacy of tramadol, plasma concentrations of the enantiomers tramadol and $O$-demethyl-tramadol were measured 30, 90, and 180 minutes after tramadol was given. ${ }^{64}$ Variability of $O$-demethyltramadol concentrations was correlated with CYP2D6 genotype (Figure 2). Concomitant use of CYP2D6 inhibitors further contributed to variability of tramadol metabolism. Poor efficacy of tramadol analgesia with the need for rescue medication was increased fourfold in PMs. Intoxication or adverse effects after tramadol analgesia in individuals with CYP2D6 duplication have also been reported. Dizziness resulting in hospitalization, respiratory depression requiring naloxone, and a near-fatal cardiotoxicity following tramadol were reported in individuals that were genotyped and found to be UMs. ${ }^{31,66,67}$

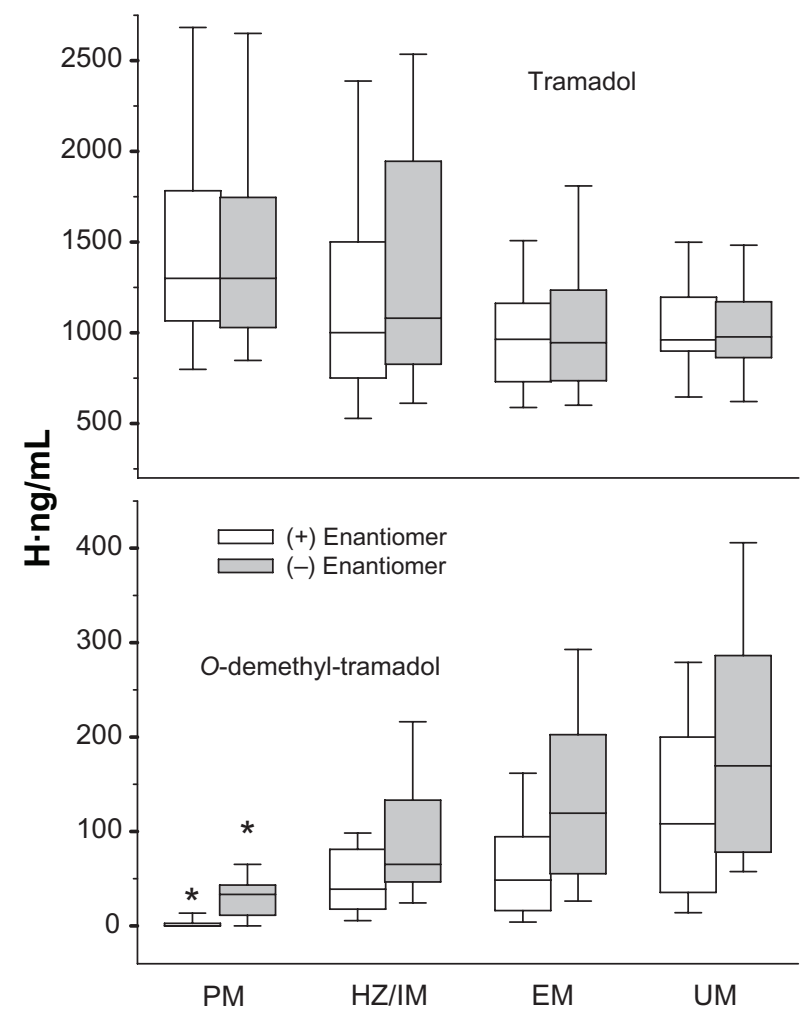

Figure 2 Concentrations of tramadol and enantiomers in different CYP2D6 genotypes. Adapted with permission from Macmillan Publishers Ltd: Stamer et al. Clin Pharmacol Ther. 2007; 82:41-47.64

Abbreviations: $\mathrm{PM}$, poor metabolizers; $\mathrm{HZ} / \mathrm{IM}$, heterozygous individual/intermediate metabolizer; EM, extensive metabolizer; UM, ultra rapid metabolizer. ${ }^{*} P<0.001$ (Kruskal-Wallis test).
Some similarities with codeine were found with regards to lactating mothers and $O$-demethyl-tramadol transfer in breast milk. ${ }^{68}$ In women treated with tramadol 50 or $100 \mathrm{mg}$ four to six times daily, the calculated mean $O$-demethyltramadol concentration in milk was $1187 \mathrm{nmol} / \mathrm{L}$ for EMs and $602 \mathrm{nmol} / \mathrm{L}$ for PMs, which are close to measured values reported in a pharmacokinetic modeling study. ${ }^{69}$ Mean estimates of relative infant dose of tramadol in EM mothers were $2.16 \%$, in PM mothers $2.6 \%$, and of $O$-demethyl-tramadol $0.93 \%$ and $0.47 \%$, respectively. ${ }^{68}$ Since none of the infant dose in tramadol equivalents was higher than the generally suggested $10 \%$ limit, maternal tramadol administration is considered safe, although the authors did recommend caution in individual infants. ${ }^{68}$

In addition to CYP2D6, the organic cation transporter OCT1 also contributes to the pharmacokinetics of $O$-demethyl-tramadol. OCT1 is most abundantly expressed in the liver and mediates the cellular uptake of this active tramadol metabolite. ${ }^{70}$ The $O$-demethyl-tramadol uptake in vitro is 2.4 fold higher in OCT1-overexpressing cells than in control cells. In vivo common genetic polymorphisms of this transporter resulting in reduced or absent OCT1 activity were correlated with higher plasma concentrations of $O$-demethyl-tramadol and a prolonged opioid-induced miosis. These data suggest that OCT1 activity is related to hepatic reuptake of $O$-demethyltramadol before glucuronidation and elimination. ${ }^{70,71}$ More work has to be done in this field to understand the complex interplay between CYP2D6 genotypes, the influence of OCT1, and other candidate genes.

\section{Oxycodone}

Oxycodone is a semisynthetic opioid agonist and is widely used as an analgesic for both acute and chronic pain. Both oxycodone and oxymorphone, one of its metabolites, are potent analgesics used for chronic pain. Since the introduction of controlled-release oxycodone in 1995, annual prescriptions of oxycodone have steadily increased several-fold. ${ }^{72}$ Oxycodone undergoes metabolism in the liver through four different metabolic pathways catalyzed by CYP3A4 and CYP2D6 (Figure 1). $\mathrm{N}$-demethylation of oxycodone by CYP3A4 into noroxycodone is quantitatively the most important metabolic route $(45 \% \pm 21 \%)$, while a smaller fraction $(11 \% \pm 6 \%)$ of oxycodone is $O$-demethylated to oxymorphone by CYP2D6. ${ }^{73}$ The resulting metabolites, when compared to morphine, have different affinities for the $\mu$-opioid receptor, ${ }^{74}$ from highest to lowest: oxymorphone $>$ morphine $>$ noroxymorphone $>$ oxycodone $>$ noroxycodone. The importance of an intact CYP3A4 pathway for oxycodone clearance has been 
emphasized in numerous pharmacokinetic studies. ${ }^{73,75-80}$ Many drugs, ${ }^{79-86}$ as well as grapefruit juice intake, ${ }^{87}$ have been shown to interfere with this pathway. Noroxymorphone is a metabolite of noroxycodone and oxymorphone that is a potent $\mu$-agonist when administered intrathecally, but that lacks analgesic activity after systemic administration, probably because of an a priori poor blood-brain barrier penetration. ${ }^{88}$ Early studies describing the impact of CYP2D6 metabolism (phenotype) on clinical outcomes of oxycodone (analgesia and side effects) have demonstrated a weaker effect in PMs. ${ }^{89,90}$ Anecdotic cases of adverse effects after oxycodone in CYP2D6 PMs have been reported..$^{91}$

Despite its widespread and increasing use for pain management and postoperative analgesia, evidence related to the pharmacogenetic influence of CYP3A4 and CYP2D6 on the clinical response (analgesic and side-effect profile) of oxycodone or oxymorphone is particularly scarce. Oxycodone analgesia and side effects were evaluated in ten healthy Caucasian volunteers (all men) phenotyped and genotyped for CYP2D6. ${ }^{92}$ Experimental pain tests were performed in a five-arm crossover, randomized, double-blinded, placebo-controlled manner, with oral oxycodone $0.2 \mathrm{mg} / \mathrm{kg}$. Differences in analgesia were found with increased analgesic effects in UMs; conversely, PMs had a two- to twentyfold reduction of analgesia compared to EMs. Notable differences in the incidence of spontaneously reported adverse reactions after oxycodone were reported by $2 / 2 \mathrm{UM}$, in comparison to only 1/6 EM and no toxicity reported in IM and PM (0/2). Importantly, CYP3A4 blockade, such as that which occurs with itraconazole, increased the analgesic efficacy of oxycodone as well as the toxicity of oxycodone, especially in CYP2D6 UMs. These findings are consistent with reports of life-threatening events in ultrarapid metabolizers receiving codeine. . $^{30,39,41}$

The effects of itraconazole, an inhibitor of the CYP3A4mediated $N$-demethylation of oxycodone, were evaluated after administration of oxycodone $(0.1 \mathrm{mg}$ IV and $10 \mathrm{mg}$ orally) in eleven healthy Caucasian subjects. ${ }^{86}$ Itraconazole affected the metabolism of oxycodone to a greater extent when oxycodone was given orally. As a result, dose adjustments of oral oxycodone may be necessary in CYP3A4 poor metabolizers to avoid opioid-related adverse effects.

Another report on the effect of oxycodone analgesia according to CYP2D6 genotype evaluated 33 healthy Caucasian volunteers undergoing nociceptive tests (five experimental modalities) in a placebo-controlled doubleblinded study. ${ }^{93}$ All subjects were evaluated after receiving either placebo or $20 \mathrm{mg}$ oxycodone orally during two separate study sessions in a randomized fashion. Subjects were classified into two groups (rather than the four possible genotypic groups based on allelic function): intermediate, extensive, and ultrarapid metabolizers were pooled into a composite group (called "EM"); and poor metabolizers (PM) were analyzed separately according to CYP2D6 genotype and pharmacokinetic assays. Oxycodone resulted in marked analgesia to all pain modalities in all subjects, with a difference in the extent of analgesia depending on the pain modality. The analgesic effect of oxycodone was less pronounced in the 16 PM subjects, mainly due to a marked increase in analgesia in EM subjects occurring 1-2 hours after the oxycodone dose. The results indicate that oxycodone metabolism to oxymorphone contributes to the analgesic effect but is not responsible for all of its effect.

A follow-up study by the same authors investigated the pharmacogenetic effect of CYP2D6 on oxycodone for postoperative analgesia. ${ }^{94} \mathrm{~A}$ total of 270 Caucasian patients undergoing surgery received postoperative analgesia with intravenous oxycodone via IV patient-controlled analgesia (PCA) for 24 hours. There was no difference in overall oxycodone consumption, pain ratings, or side effects between genotype groups despite a significant difference in plasma concentrations. The mean oxymorphone/oxycodone ratio was substantially higher in EM compared to PM subjects. One of the shortcomings of this study is that no genetic test for the UM status was performed, and possibly individuals might have been misclassified to the EM group. Furthermore, pain scores and analgesic consumption were low, and a differentiation of genotypes might not have been possible due to overall low analgesic needs. In another recent study in Caucasian cancer patients managed with oral oxycodone, oxymorphone/oxycodone ratios differed between genotypes. However, this did not translate into any measurable difference in clinical outcomes (pain intensity, nausea, tiredness, or cognitive function). ${ }^{95}$

Overall, the level of evidence linking genetic variability (CYP2D6 and CYP3A4) to phenotype (altered biotransformation of oxycodone into oxymorphone and overall clearance of oxycodone and oxymorphone) is strong; however, there has been no randomized clinical trial on the benefits of genetic testing prior to oxycodone therapy. There is also no warning on the oxycodone label cautioning against prescription of oxycodone in CYP2D6 UMs or in patients taking CYP3A4 inhibitors concomitantly. Given the widespread use and potential abuse of oxycodone prescription, further studies should certainly investigate this phenotype/genotype association. 


\section{Methadone}

Methadone is a synthetic opioid best known for its use in the treatment of opioid dependence and is considered a second-line option in the setting of neuropathic pain in cancer patients. ${ }^{96,97}$ Methadone occurs in $R$ - and $S$-enantiomeric forms, with essentially all of its activity due to $R$-methadone. Both enantiomers bind to the noncompetitive site of the $N$-methyl-D-aspartate receptor; ${ }^{26}$ however, $R$-methadone (levomethadone) is a tenfold stronger $\mu$-opioid receptor agonist than $S$-methadone. ${ }^{98} S$-methadone on the other hand seems to be related to side effects (eg, increased QTc intervals in the electrocardiogram). ${ }^{99}$ The $N$-methyl-D-aspartate antagonistic effect explains the popularity of methadone as second-line opioid, and its place in opioid switching when conventional opioids fail to provide satisfactory pain relief. ${ }^{100}$ With regard to methadone metabolism, a great variation in plasma concentration of the different enantiomers has been shown. CYP3A4 and CYP2B6 are the major CYP isoforms involved in methadone metabolism, with CYP2D6 only contributing in a negligible manner, with close to no impact on methadone dosage requirements. ${ }^{101-104} A B C B 1$ genetic polymorphisms do contribute slightly to the interindividual variability of methadone kinetics. ${ }^{102,103,105,106} \mathrm{CYP} 2 \mathrm{~B} 6$ activity is clearly associated with altered pharmacokinetics, clinical outcome and adverse effects. ${ }^{107-110}$ Methadone should be carefully administered in patients using CYP3A inhibitors ${ }^{104}$ or drugs inhibiting CYP2B6. ${ }^{110}$

\section{OPRMI polymorphism, pain perception, and opioid analgesia}

Among the numerous candidate genes that have been considered important in opioid response, the $\mu$-opioid receptor gene (OPRMI) is probably the best studied. A common polymorphism of $O P R M 1$ is a single nucleotide substitution at position 118, with an adenine substitution by a guanine (A118G) reported to occur with an allelic frequency of 10\%-30\% among Caucasians, ${ }^{111}$ a higher prevalence among Asians, ${ }^{112}$ and a lower one in African-Americans. ${ }^{113}$ The major interest for this particular polymorphism is due to its pharmacological and physiological consequences; however, the exact mechanism by which the altered receptor influences opioid analgesia is still unresolved. In vitro studies have suggested that $\mathrm{A} 118 \mathrm{G}$ polymorphism affects receptor binding characteristics ${ }^{114,115}$ or messenger RNA expression levels; ${ }^{116}$ however, under some experimental conditions, there was no effect on function ${ }^{117}$ or expression levels. ${ }^{118}$ In a recent humanized mouse model exploring signal transduction pathways that mediate opioid pharmacology, sensory neurons expressing the $118 G G$ gene displayed reduced morphine (but not fentanyl) potency and efficacy compared with the $118 \mathrm{AA}$ version. This suggests that the genetic effect is at least at the level of the sensory neurons. ${ }^{119}$

\section{Experimental pain}

Individuals carrying the variant receptor gene (G118) could show differences in some of the functions mediated by $\beta$-endorphin action and exogenous opioids. Human volunteers (male and female) carrying a G118 allele exhibited lower sensitivity to pressure pain (ie, higher tolerance threshold to pressure pain) compared with A118 homozygotes. ${ }^{120}$ However, the association between genotype and pain perception is not that simple; a significant interaction between sex and genotype for heat-pain ratings at $49^{\circ} \mathrm{C}$ was identified, indicating that the variant $G 118$ allele was associated with lower pain ratings among men but higher pain ratings among women. A study in a Han Chinese cohort of healthy female volunteers demonstrated that pressure-pain threshold is influenced by another polymorphism of OPRM1 (IVS2 + A31G) but not the A118G polymorphism. ${ }^{121}$ Other studies assessing the influence of genetic variants on experimental pain demonstrated no effect of OPRM1 A118G genotype on pain processing ${ }^{122}$ or lower pain-tolerance thresholds to single electrical nerve stimulation in individuals carrying the $G 118$ allele. ${ }^{123}$ It has been determined that the effect size of various determinants for experimental pain perception is greatest for heat sensitization by capsaicin, followed by gender (higher pain sensitivity in women) and a more modest effect size for genetic determinants. ${ }^{33}$ Therefore, cautious interpretation of experimental pain tests should take into account ethnicity (population admixture), the noxious stimulus, and gender, as well as possible linkage disequilibrium with other polymorphisms that may represent the true functional genetic variant.

\section{Neuraxial opioids for labor analgesia}

Using the up-down sequential allocation model to identify differences in analgesic requirement according to OPRMI genotype in women requesting neuraxial analgesia early in labor, women carrying the G118 allele required substantially lower doses of spinal fentanyl, with a 1.5 -fold difference compared to wild types. ${ }^{124}$ This finding was replicated with a different pharmacological study design using random-dose allocation, with a twofold difference between genetic groups. ${ }^{124}$ Of note, cervical dilatation at the time of analgesia request was significantly less in $118 \mathrm{AA}$ women than that in women carrying one or two variant 
alleles (118 AG or $118 \mathrm{GG})$. The finding of lower analgesic requirements at a more advanced stage in labor is consistent with the principle that women carrying the G118 allele may have higher pain tolerance that allows them to wait longer before requesting epidural analgesia. Therefore, according to our findings, genotyping may help in improving labor analgesia, because $30 \%$ of Caucasian women (and probably a vast majority of Asian women) may in fact require significantly lower doses of spinal fentanyl during labor. On the other hand, the duration of spinal fentanyl analgesia does not appear to be influenced by A118G genotype, ${ }^{125}$ suggesting that this SNP may influence spinal fentanyl potency without affecting the duration of analgesic action. Using the same methodology, a recent study demonstrated a similar pharmacogenetic association, although with a more modest effect, with lower dose requirement for epidural sufentanil in women carrying the variant $\mathrm{G}$ allele. ${ }^{126}$

\section{Spinal and systemic morphine for postoperative analgesia}

The effect of the $\mathrm{A} 118 \mathrm{G}$ polymorphism of $O P R M 1$ on postcesarean analgesia after spinal and IV morphine was also evaluated in three recent studies with variable outcomes. ${ }^{125,127,128}$ One study found no differences in the duration of spinal morphine analgesia, the need for analgesic supplementation or the incidence of nausea according to A118G genotype; however, pruritus was less frequent in carriers of the $G 118$ allele during the first 24 hours. ${ }^{125}$ In Asian women, however, with a slightly different analgesic regimen, G118 carriers exhibited increased 24-hour postoperative consumption of morphine via IV PCA. ${ }^{127}$ In a multiple regression analysis, the most important factor contributing to morphine usage was maximum pain score, followed by ethnicity and A118G polymorphism. ${ }^{129}$ After correction for genotype, ethnicity was still a significant contributing factor, with Indian women reporting higher pain scores and using higher doses of IV morphine.

Although the analysis and interpretation of specific allelic combination of multiple SNPs is often challenging, ${ }^{130,131}$ morphine consumption via IV PCA for management of acute postoperative pain, in the nonobstetric context, has been shown to be higher in patients carrying the G118 allele. ${ }^{132-135}$ The effect may be modest and not clinically relevant.

Overall, inconsistent findings across studies investigating opioid analgesia according to OPRM1 genotype may be due to the fact that spinal and systemic opioid pharmacokinetics and pharmacodynamics may be different; enhanced analgesia in response to spinal fentanyl in the presence of the
G118 allele may not exist in response to IV fentanyl or other opioids via the IV route. Or one could speculate that human spinal cord receptor function and signal transduction is selectively more altered by the $G 118$ variant than supraspinal receptors. Another potential explanation and factor to bear in mind is the different nature of the nociceptive stimulus in labor (predominantly a visceral component in early labor) versus other painful syndromes.

\section{Systemic fentanyl for postoperative analgesia}

Recent studies evaluating postoperative IV consumption of fentanyl according to A118G polymorphism of OPRMI after surgery in various Asian cohorts revealed lower fentanyl requirements in A118G-homozygous individuals (Table 2). ${ }^{136-139}$ Potential explanations for these varying findings are that labor pain is different from that tested by experimental models of pain or that experienced in other clinical settings (postoperative or chronic pain), or that the response to systemic administration of fentanyl, rather than spinal, is affected differently by OPRMI genotype. Alternatively, it may be that other factors, including ethnicity, influence the effect of genetic variants of OPRM1.

In a Japanese cohort of healthy individuals undergoing surgery, a baseline preoperative cold pressor test was better tolerated in $118 \mathrm{AA}$ individuals, and the response to fentanyl was enhanced in these subjects; however, there was no difference in pain ratings or fentanyl consumption during the first 24 hours after surgery. ${ }^{138}$ Women, on the other hand, required more fentanyl postoperatively than men. Another polymorphism of the OPRM1 gene (IVS3 + A8449G SNP in intron 3 ), present in $22 \%$ of individuals in this cohort, did alter the clinical effect of fentanyl, with a modest reduction of total postoperative IV PCA use of fentanyl in carriers of the minor $\mathrm{G}$ allele of this SNP. A study in Han Chinese patients undergoing laparoscopic abdominal surgery concluded that individuals carrying the $G 118$ allele have a shorter time to awakening and extubation, and experience reduced analgesic efficacy of fentanyl with no clinically significant changes in respiratory depression. ${ }^{139}$ In another study in a Han Chinese cohort of women undergoing elective hysterectomies, pain thresholds after electric stimulation did not differ between genotypic groups; however, there was a difference for pain tolerance with this experimental model of pain. Pain-tolerance threshold was lower in women carrying the minor $G 118$ allele, and there was no difference in postoperative pain scores; however, IV PCA fentanyl consumption was higher in women carrying the $G 118$ allele. ${ }^{136}$ The same authors did 
Table 2 OPRMI genotype and fentanyl requirement

\begin{tabular}{|c|c|c|c|c|}
\hline $\begin{array}{l}\text { Subjects } \\
{[\mathrm{n}]}\end{array}$ & Study cohort & Route of administration & Measured outcomes & $\begin{array}{l}\text { Observed associations } \\
\text { in GI/ } 8 \text { carriers }\end{array}$ \\
\hline $\begin{array}{l}223 \\
{[124]}\end{array}$ & $\begin{array}{l}\text { Nulliparous women } \\
\text { in early labor }\end{array}$ & $\begin{array}{l}\text { Spinal (up-down sequential } \\
\text { and randomized doses) }\end{array}$ & $\begin{array}{l}\mathrm{ED}_{50} \text { (median effective dose } \\
\text { providing } 60 \text { minutes } \\
\text { of early labor analgesia) }\end{array}$ & $\begin{array}{l}\text { Analgesia requested at later stage } \\
\text { (greater cervical dilatation) } \\
\text { Lower spinal fentanyl dose }\left(\mathrm{ED}_{50}\right)\end{array}$ \\
\hline $\begin{array}{l}147 \\
{[125]}\end{array}$ & $\begin{array}{l}\text { Nulliparous women } \\
\text { in early labor }\end{array}$ & Spinal (25 mcg) & $\begin{array}{l}\text { Duration of effective analgesia } \\
\text { in early labor }\end{array}$ & No difference in duration of analgesia \\
\hline $\begin{array}{l}280 \\
{[137]}\end{array}$ & $\begin{array}{l}\text { Healthy Japanese, } \\
\text { orodental surgery }\end{array}$ & $\begin{array}{l}\text { - Preop IV test }(2 \mathrm{mcg} / \mathrm{kg}) \\
\text { - Postop IV PCA } \\
\text { ( } 40 \mathrm{mcg} / \mathrm{I} 0 \text { minutes })\end{array}$ & $\begin{array}{l}\text { - Cold-pressor test } \\
\text { before vs after IV dose } \\
\text { - 24-hour postop IV PCA } \\
\text { consumption }\end{array}$ & $\begin{array}{l}\text { Pre-IV test: increased sensitivity } \\
\text { Post-IV test: reduced analgesic effect } \\
\text { Reduced fentanyl sensitivity in women vs men } \\
\text { No difference in VAS scores and 24-hae } \\
\text { postop fentanyl consumption }\end{array}$ \\
\hline $\begin{array}{l}189 \\
{[139]}\end{array}$ & $\begin{array}{l}\text { Han Chinese, } \\
\text { laparoscopic } \\
\text { abdominal surgery }\end{array}$ & $\begin{array}{l}\text { - } \text { Preop IV (5 mcg/kg) } \\
\text { - Intraop IV } \\
\text { (I mcg/kg/30 minutes) } \\
\text { - Postop IV (I mcg/kg) }\end{array}$ & $\begin{array}{l}\text { - Postop pain scores } \\
\text { (I5, 30, 45, } 60 \text { minutes) } \\
\text { - Time to awakening } \\
\text { - Respiratory depression } \\
\text { - } \mathrm{PaCO}_{2}\end{array}$ & $\begin{array}{l}\text { Higher pain scores (at } 15 \text { and } 30 \text { minutes) } \\
\text { Shorter time for awakening } \\
\text { Lower } \mathrm{PaCO}_{2}\end{array}$ \\
\hline $\begin{array}{l}174 \\
{[136]}\end{array}$ & $\begin{array}{l}\text { Han Chinese, } \\
\text { hysterectomy }\end{array}$ & $\begin{array}{l}\text { - Preextubation (I mcg/kg) } \\
\text { - Postop IV PCA } \\
\text { (continuous } 5 \mathrm{mcg} / \mathrm{hour}, \\
\text { bolus } 20 \mathrm{mcg} / 5 \text { minutes) }\end{array}$ & $\begin{array}{l}\text { - Preop electrical pain } \\
\text { threshold } \\
\text { - } 24 \text {-hour postop VAS scores } \\
\text { - } 24 \text {-hour postop IV PCA } \\
\text { consumption }\end{array}$ & $\begin{array}{l}\text { No difference in pain threshold } \\
\text { Lower electrical pain tolerance threshold } \\
\text { (gene-dose-dependent effect) } \\
\text { No difference of initial postop or averaged } \\
\text { 24-hour pain scores } \\
\text { Higher consumption of postop fentanyl } \\
\text { Trend for lower incidence PONV }\end{array}$ \\
\hline
\end{tabular}

Abbreviations: IV, intravenous; PCA, patient-controlled analgesia; VAS, visual analog scale; PONV, postoperative nausea and vomiting.

not find an association between $A 118 G$ genotype and the incidence of nausea and vomiting caused by fentanyl for postoperative pain. ${ }^{140}$

Finally, subjects carrying the $G 118$ allele complained of more severe pain during shock-wave lithotripsy, despite self-administration of higher doses of alfentanil, reaching higher plasma alfentanil concentrations. This indicates that carriers of the minor $G 118$ allele may experience impaired analgesia in response to alfentanil. ${ }^{141}$ The advantage of this model of clinical pain and anesthetic protocol resides in the fact that patients received only alfentanil, and therefore pharmacokinetic/dynamic interactions resulting from concomitant medications are unlikely to have confounded the findings.

\section{Morphine for cancer pain}

Screening for A118G genotype in a cohort of cancer patients on oral morphine initially revealed that individuals homozygous for the G118 allele required higher morphine doses for adequate pain control. ${ }^{142}$ In addition, combining this genotype with other gene variants ( $A B C B 1$ or $C O M T)$ seemed to confirm an association of these polymorphisms with morphine requirements. ${ }^{143,144}$ However, subsequent larger trials did not confirm that oral morphine consumption for chronic pain (eg, cancer pain) could be reliably predicted by A118G genotype. ${ }^{145,146}$ In particular, a large European multicenter study found no association between 112 SNPs in 25 candidate genes, including OPRM1 and COMT, and opioid dose (morphine, oxycodone, or fentanyl primarily) in a cohort of 2294 cancer patients. ${ }^{145}$ While no joint combined allelic combination was evaluated, this trial does fail to validate associations related to opioid efficacy reported in several previous association studies, and with the current body of knowledge argues against including pharmacogenetic testing for improvements in clinical decision-making for opioid prescription.

\section{COMT gene, pain and opioid analgesia}

Among the usual candidate genes proposed, the Val158Met polymorphism of the catechol-O-methyltransferase (COMT) gene that regulates the metabolism of dopamine and noradrenaline may be identified as potentially inferring an increased risk for the development of chronic pain disorders, ${ }^{147}$ acute postoperative pain, ${ }^{36,135}$ chronic postsurgical pain, ${ }^{148}$ and opioid-induced hyperalgesia. ${ }^{149}$ High COMT activity, as found with the Val158 allele, is associated with improved dopaminergic transmission and has been suggested 
to confer an advantage in the processing of aversive stimuli or stressful conditions (warrior strategy), while Met158 alleles may be associated with an advantage in memory and attention tasks (worrier strategy). ${ }^{150}$ Individuals homozygous for the Met 158 allele display increased pain sensitivity, and there are findings of lower $\mu$-opioid system activation during sustained pain. ${ }^{151-153}$ The interplay between COMT inhibition and pain sensitivity mediated by $\beta 2$ and $\beta 3$ adrenergic receptor modulation has been highlighted, ${ }^{154}$ and response to propranolol for management of temporomandibular pain has been shown to be predicted by COMT haplotype. ${ }^{155} \mathrm{In}$ a recent study evaluating repeated thermal-pain stimulation before and after a single opiate dose in a Caucasian cohort, the Val158Met genotype did not influence the reaction to the initial noxious stimulus or the analgesic response to intravenous remifentanil administration. ${ }^{149}$ However, after repeated heat stimulation and post-remifentanil administration, pain ratings in Met 158 individuals were significantly higher, suggesting that initial pain response is not influenced by COMT and that differences may become apparent only after endogenous pain modulation is challenged. The increased pain sensitivity in Met158 individuals following remifentanil could result from reduced efficacy of endogenous pain modulation and/or increased susceptibility to opioid-induced hyperalgesia. The suggestion that the effect of COMT genotype on pain processing becomes apparent only when the pain modulation is challenged, such as occurs after repeated pain stimulation, was confirmed in a functional magnetic resonance imaging study investigating brain responses to thermal pain stimuli. ${ }^{156}$

\section{The future of personalized medicine}

Contrasting results in human genetic studies of pain sensitivity have been shown to occur with each of the usual polymorphisms assessed. ${ }^{157,158}$ This illustrates the challenges in evaluating a genotype-phenotype association when the underlying genetic susceptibility is clearly polygenic, and genotyping of allelic combinations should be done concomitantly. ${ }^{48}$ The phenotype is indeed complex in itself, representing subjective and multifactorial pain perception experiences and/or responses to pain-modulating drugs. Numerous candidate genes as well as elaborate models have been suggested for the study of the genetic component of pain. Nonetheless, due to the inherent complexity in the study of pain, involving different nociceptive modalities, gender differences, limitations in extrapolating data from animal models to human perception, interethnic and environmental differences in addition to the obvious polygenic nature of pain, it is the design and execution of large clinical studies analyzing multiple haplotypes simultaneously that remains the true challenge to date. Meanwhile, genome-wide association studies in the context of acute postoperative pain are being published, ${ }^{159}$ and researchers are already actively working on gene therapies for chronic pain. ${ }^{160-162}$

\section{Conclusion}

To improve clinical outcomes based on pharmacogenetic testing in the context of pain therapies, genotyping of CYP isozymes is likely to become strongly recommended. The individual pharmacokinetic profile and possible drug-drug interactions with potentially devastating outcomes for opioids relying on CYP2D6 and CYP3A4 metabolism are well-recognized major variables influencing the pharmacotherapy of pain. On the other hand, predicting the analgesic response to morphine based on pharmacogenetic testing is more complex; though there was hope that simple genetic testing would allow tailoring morphine doses to provide optimal analgesia, this is unlikely to occur. Different polymorphisms clearly influence pain perception and behavior in response to pain. However, the response to analgesics also differs depending on the pain modality and the potential for repeated noxious stimuli, the opioid prescribed, and even its route of administration.

\section{Acknowledgments}

Ruth Landau is the recipient of Swiss National Foundation Research grant SNF 3200B0-114129 that funded in part the OPRM1 genetic research conducted in Switzerland. Pascal H Vuilleumier is the recipient of Swiss National Foundation Research grant SPUM 33CM30-1241117.

\section{Disclosure}

The authors declare no conflicts of interest.

\section{References}

1. Flockhart DA, Skaar T, Berlin DS, Klein TE, Nguyen AT. Clinically available pharmacogenomics tests. Clin Pharmacol Ther. 2009;86: 109-113.

2. Frueh FW, Amur S, Mummaneni P, et al. Pharmacogenomic biomarker information in drug labels approved by the United States food and drug administration: prevalence of related drug use. Pharmacotherapy. 2008;28:992-998

3. Sim SC, Ingelman-Sundberg M. Pharmacogenomic biomarkers: new tools in current and future drug therapy. Trends Pharmacol Sci. 2011;32:72-81.

4. Relling MV, Klein TE. CPIC: Clinical Pharmacogenetics Implementation Consortium of the Pharmacogenomics Research Network. Clin Pharmacol Ther. 2011;89:464-467. 
5. Johnson JA, Gong L, Whirl-Carrillo M, et al. Clinical Pharmacogenetics Implementation Consortium Guidelines for CYP2C9 and VKORC1 genotypes and warfarin dosing. Clin Pharmacol Ther. 2011;90: 625-629.

6. Scott SA, Sangkuhl K, Gardner EE, et al. Clinical Pharmacogenetics Implementation Consortium guidelines for cytochrome P450-452C19 (CYP2C19) genotype and clopidogrel therapy. Clin Pharmacol Ther. 2011;90:328-332.

7. Relling MV, Gardner EE, Sandborn WJ, et al. Clinical Pharmacogenetics Implementation Consortium guidelines for thiopurine methyltransferase genotype and thiopurine dosing. Clin Pharmacol Ther. 2011;89:387-391.

8. Crews KR, Gaedigk A, Dunnenberger HM, et al. Clinical Pharmacogenetics Implementation Consortium (CPIC) Guidelines for codeine therapy in the context of cytochrome P450 2D6 (CYP2D6) genotype. Clin Pharmacol Ther. 2012;91:321-326.

9. Kehlet H, Jensen TS, Woolf CJ. Persistent postsurgical pain: risk factors and prevention. Lancet. 2006;367:1618-1625.

10. Cavallari L, Jeong H, Bress A. Role of cytochrome P450 genotype in the steps toward personalized drug therapy. Pharmgenomics Pers Med. 2011;4:123-136.

11. Nielsen CS, Staud R, Price DD. Individual differences in pain sensitivity: measurement, causation, and consequences. J Pain. 2009; 10: 231-237.

12. Smith HS. Variations in opioid responsiveness. Pain Physician. 2008;11:237-248

13. Angst MS, Phillips NG, Drover DR, et al. Opioid pharmacogenomics using a twin study paradigm: methods and procedures for determining familial aggregation and heritability. Twin Res Hum Genet. 2010;13:412-425.

14. Nielsen CS, Stubhaug A, Price DD, Vassend O, Czajkowski N, Harris JR. Individual differences in pain sensitivity: genetic and environmental contributions. Pain. 2008;136:21-29.

15. Foulkes T, Wood JN. Pain genes. PloS Genet. 2008;4:e1000086.

16. Diatchenko L, Nackley AG, Tchivileva IE, Shabalina SA, Maixner W. Genetic architecture of human pain perception. Trends Genet. 2007;23: 605-613.

17. Cox JJ, Reimann F, Nicholas AK, et al. An SCN9A channelopathy causes congenital inability to experience pain. Nature. 2006;444:894-898.

18. Nilsen KB, Nicholas AK, Woods CG, Mellgren SI, Nebuchennykh M, Aasly J. Two novel SCN9A mutations causing insensitivity to pain. Pain. 2009;143:155-158.

19. Goldberg YP, Price N, Namdari R, et al. Treatment of $\mathrm{Na}(\mathrm{v})$ 1.7-mediated pain in inherited erythromelalgia using a novel sodium channel blocker. Pain. 2012;153:80-85.

20. Nguyen HN, Bregman H, Buchanan JL, et al. Discovery and optimization of aminopyrimidinones as potent and state-dependent Nav1.7 antagonists. Bioorg Med Chem Lett. 2012;22:1055-1060.

21. Goldberg YP, MacFarlane J, MacDonald ML, et al. Loss-of-function mutations in the Nav1.7 gene underlie congenital indifference to pain in multiple human populations. Clin Genet. 2007;71:311-319.

22. Fillingim RB, King CD, Ribeiro-Dasilva MC, Rahim-Williams B, Riley JL 3rd. Sex, gender, and pain: a review of recent clinical and experimental findings. J Pain. 2009;10:447-485.

23. Ingelman-Sundberg M, Sim SC, Gomez A, Rodriguez-Antona C. Influence of cytochrome $\mathrm{P} 450$ polymorphisms on drug therapies: pharmacogenetic, pharmacoepigenetic and clinical aspects. Pharmacol Ther. 2007;116:496-526.

24. Eichelbaum M, Ingelman-Sundberg M, Evans WE. Pharmacogenomics and individualized drug therapy. Annu Rev Med. 2006;57:119-137.

25. Wang B, Yang LP, Zhang XZ, Huang SQ, Bartlam M, Zhou SF. New insights into the structural characteristics and functional relevance of the human cytochrome P450 2D6 enzyme. Drug Metab Rev. 2009;41:573-643

26. Zhou SF. Polymorphism of human cytochrome P450 2D6 and its clinical significance: part II. Clin Pharmacokinet. 2009;48:761-804.
27. Daly AK, Brockmoller J, Broly F, et al. Nomenclature for human CYP2D6 alleles. Pharmacogenetics. 1996;6:193-201.

28. Stamer UM, Zhang L, Stuber F. Personalized therapy in pain management: where do we stand? Pharmacogenomics. 2010;11: 843-864.

29. Sistonen J, Sajantila A, Lao O, Corander J, Barbujani G, Fuselli S. CYP2D6 worldwide genetic variation shows high frequency of altered activity variants and no continental structure. Pharmacogenet Genomics. 2007; 17:93-101.

30. Gasche Y, Daali Y, Fathi M, et al. Codeine intoxication associated with ultrarapid CYP2D6 metabolism. $N$ Engl J Med. 2004;351: 2827-2831.

31. Stamer UM, Stuber F, Muders T, Musshoff F. Respiratory depression with tramadol in a patient with renal impairment and CYP2D6 gene duplication. Anesth Analg. 2008;107:926-929.

32. Mogil JS, Bailey AL. Sex and gender differences in pain and analgesia. Prog Brain Res. 2010;186:141-157.

33. Doehring A, Kusener N, Fluhr K, Neddermeyer TJ, Schneider G, Lotsch J. Effect sizes in experimental pain produced by gender, genetic variants and sensitization procedures. PloS One. 2011;6:e17724.

34. Pinto N, Dolan ME. Clinically relevant genetic variations in drug metabolizing enzymes. Curr Drug Metab. 2011;12:487-497.

35. Thorn CF, Klein TE, Altman RB. Codeine and morphine pathway. Pharmacogenet Genomics. 2009;19:556-558.

36. Lee PJ, Delaney P, Keogh J, Sleeman D, Shorten GD. Catecholamineo-methyltransferase polymorphisms are associated with postoperative pain intensity. Clin J Pain. 2011;27:93-101.

37. Derry S, Moore RA, McQuay HJ. Single dose oral codeine, as a single agent, for acute postoperative pain in adults. Cochrane Database Syst Rev. 2010;4:CD008099.

38. VanderVaart S, Berger H, Sistonen J, et al. CYP2D6 polymorphisms and codeine analgesia in postpartum pain management: a pilot study. Ther Drug Monit. 2011;33:425-432.

39. Ciszkowski C, Madadi P, Phillips MS, Lauwers AE, Koren G. Codeine, ultrarapid-metabolism genotype, and postoperative death. NEngl J Med. 2009;361:827-828.

40. Voronov P, Przybylo HJ, Jagannathan N. Apnea in a child after oral codeine: a genetic variant - an ultra-rapid metabolizer. Paediatr Anaesth. 2007;17:684-687.

41. Koren G, Cairns J, Chitayat D, Gaedigk A, Leeder SJ. Pharmacogenetics of morphine poisoning in a breastfed neonate of a codeine-prescribed mother. Lancet. 2006;368:704.

42. Meny RG, Naumburg EG, Alger LS, Brill-Miller JL, Brown S. Codeine and the breastfed neonate. J Hum Lact. 1993;9:237-240.

43. Madadi P, Koren G, Cairns J, et al. Safety of codeine during breastfeeding: fatal morphine poisoning in the breastfed neonate of a mother prescribed codeine. Can Fam Physician. 2007;53:33-35.

44. Willmann S, Edginton AN, Coboeken K, Ahr G, Lippert J. Risk to the breast-fed neonate from codeine treatment to the mother: a quantitative mechanistic modeling study. Clin Pharmacol Ther. 2009;86:634-643

45. Lotsch J, Geisslinger G. A critical appraisal of human genotyping for pain therapy. Trends Pharmacol Sci. 2010;31:312-317.

46. Madadi P, Ross CJ, Hayden MR, et al. Pharmacogenetics of neonatal opioid toxicity following maternal use of codeine during breastfeeding: a case-control study. Clin Pharmacol Ther. 2009;85:31-35.

47. Madadi P, Shirazi F, Walter FG, Koren G. Establishing causality of CNS depression in breastfed infants following maternal codeine use. Paediatr Drugs. 2008;10:399-404.

48. Lotsch J, Fluhr K, Neddermayer T, Doehring A, Geisslinger G. The consequence of concomitantly present functional genetic variants for the identification of functional genotype-phenotype associations in pain. Clin Pharmacol Ther. 2009;85:25-30.

49. de Leon J, Susce MT, Murray-Carmichael E. The AmpliChip CYP450 genotyping test: integrating a new clinical tool. Mol Diagn Ther. 2006;10:135-151. 
50. Lotsch J, Rohrbacher M, Schmidt H, Doehring A, Brockmoller J, Geisslinger G. Can extremely low or high morphine formation from codeine be predicted prior to therapy initiation? Pain. 2009;144:119-124.

51. Wilder-Smith $\mathrm{CH}$, Hufschmid E, Thormann W. The visceral and somatic antinociceptive effects of dihydrocodeine and its metabolite, dihydromorphine. A cross-over study with extensive and quinidine-induced poor metabolizers. Br J Clin Pharmacol. 1998;45:575-581.

52. Webb JA, Rostami-Hodjegan A, Abdul-Manap R, Hofmann U, Mikus G, Kamali F. Contribution of dihydrocodeine and dihydromorphine to analgesia following dihydrocodeine administration in man: a PK-PD modelling analysis. Br J Clin Pharmacol. 2001;52: 35-43.

53. Otton SV, Schadel M, Cheung SW, Kaplan HL, Busto UE, Sellers EM. CYP2D6 phenotype determines the metabolic conversion of hydrocodone to hydromorphone. Clin Pharmacol Ther. 1993;54:463-472.

54. Hutchinson MR, Menelaou A, Foster DJ, Coller JK, Somogyi AA. CYP2D6 and CYP3A4 involvement in the primary oxidative metabolism of hydrocodone by human liver microsomes. Br J Clin Pharmacol. 2004;57:287-297.

55. Kaplan HL, Busto UE, Baylon GJ, et al. Inhibition of cytochrome P450 2D6 metabolism of hydrocodone to hydromorphone does not importantly affect abuse liability. J Pharmacol Exp Ther. 1997;281:103-108.

56. Madadi P, Hildebrandt D, Gong IY, et al. Fatal hydrocodone overdose in a child: pharmacogenetics and drug interactions. Pediatrics. 2010;126:e986-e989.

57. Grond S, Sablotzki A. Clinical pharmacology of tramadol. Clin Pharmacokinet. 2004;43:879-923.

58. Enggaard TP, Poulsen L, Arendt-Nielsen L, Brosen K, Ossig J, Sindrup SH. The analgesic effect of tramadol after intravenous injection in healthy volunteers in relation to CYP2D6. Anesth Analg 2006;102:146-150.

59. Garcia-Quetglas E, Azanza JR, Sadaba B, Munoz MJ, Gil I, Campanero MA. Pharmacokinetics of tramadol enantiomers and their respective phase I metabolites in relation to CYP2D6 phenotype. Pharmacol Res. 2007;55:122-130.

60. Kirchheiner J, Keulen JT, Bauer S, Roots I, Brockmoller J. Effects of the CYP2D6 gene duplication on the pharmacokinetics and pharmacodynamics of tramadol. J Clin Psychopharmacol. 2008;28:78-83.

61. Pedersen RS, Damkier P, Brosen K. Tramadol as a new probe for cytochrome P450 2D6 phenotyping: a population study. Clin Pharmacol Ther. 2005;77:458-467.

62. Pedersen RS, Damkier P, Brosen K. Enantioselective pharmacokinetics of tramadol in CYP2D6 extensive and poor metabolizers. Eur J Clin Pharmacol. 2006;62:513-521.

63. Stamer UM, Lehnen K, Hothker F, et al. Impact of CYP2D6 genotype on postoperative tramadol analgesia. Pain. 2003;105:231-238.

64. Stamer UM, Musshoff F, Kobilay M, Madea B, Hoeft A, Stuber F. Concentrations of tramadol and $O$-desmethyl-tramadol enantiomers in different CYP2D6 genotypes. Clin Pharmacol Ther. 2007; $82: 41-47$.

65. Wang G, Zhang H, He F, Fang X. Effect of the CYP2D6*10 C188T polymorphism on postoperative tramadol analgesia in a Chinese population. Eur J Clin Pharmacol. 2006;62:927-931.

66. EichhornA, Barth J. Chronic dizziness in a pain patient-pharmacogenomic identification of tramadol as cause [German]. Rehabilitation (Stuttg). 2010;49:393-395.

67. Elkalioubie A, Allorge D, Robriquet L, et al. Near-fatal tramadol cardiotoxicity in a CYP2D6 ultrarapid metabolizer. Eur J Clin Pharmacol. 2011;67:855-858.

68. Salman S, Sy SK, Ilett KF, Page-Sharp M, Paech MJ. Population pharmacokinetic modeling of tramadol and its O-desmethyl metabolite in plasma and breast milk. Eur J Clin Pharmacol. 2011;67:899-908.

69. Ilett KF, Paech MJ, Page-Sharp M, et al. Use of a sparse sampling study design to assess transfer of tramadol and its O-desmethyl metabolite into transitional breast milk. Br J Clin Pharmacol. 2008;65: 661-666.
70. Tzvetkov MV, Saadatmand AR, Lotsch J, Tegeder I, Stingl JC, Brockmoller J. Genetically polymorphic OCT1: another piece in the puzzle of the variable pharmacokinetics and pharmacodynamics of the opioidergic drug tramadol. Clin Pharmacol Ther. 2011;90:143-150.

71. Lehtonen P, Sten T, Aitio O, et al. Glucuronidation of racemic $O$-desmethyl-tramadol, the active metabolite of tramadol. Eur J Pharm Sci. 2010;41:523-530

72. Olkkola KT, Hagelberg NM. Oxycodone: new "old” drug. Curr Opin Anaesthesiol. 2009;22:459-462.

73. Lalovic B, Kharasch E, Hoffer C, Risler L, Liu-Chen LY, Shen DD. Pharmacokinetics and pharmacodynamics of oral oxycodone in healthy human subjects: role of circulating active metabolites. Clin Pharmacol Ther. 2006;79:461-479.

74. Samer CF, Daali Y, Wagner M, et al. The effects of CYP2D6 and CYP3A activities on the pharmacokinetics of immediate release oxycodone. Br J Pharmacol. 2010;160:907-918.

75. Gronlund J, Saari TI, Hagelberg NM, Neuvonen PJ, Laine K, Olkkola KT. Effect of inhibition of cytochrome P450 enzymes 2D6 and $3 \mathrm{~A} 4$ on the pharmacokinetics of intravenous oxycodone: a randomized, three-phase, crossover, placebo-controlled study. Clin Drug Investig. 2011;31:143-153.

76. Gronlund J, Saari TI, Hagelberg NM, Neuvonen PJ, Olkkola KT, Laine K. Exposure to oral oxycodone is increased by concomitant inhibition of CYP2D6 and 3A4 pathways, but not by inhibition of CYP2D6 alone. Br J Clin Pharmacol. 2010;70:78-87.

77. Kummer O, Hammann F, Moser C, Schaller O, Drewe J, Krahenbuhl S. Effect of the inhibition of CYP3A4 or CYP2D6 on the pharmacokinetics and pharmacodynamics of oxycodone. Eur J Clin Pharmacol. 2011;67:63-71.

78. Liukas A, Hagelberg NM, Kuusniemi K, Neuvonen PJ, Olkkola KT. Inhibition of cytochrome P450 3A by clarithromycin uniformly affects the pharmacokinetics and pharmacodynamics of oxycodone in young and elderly volunteers. J Clin Psychopharmacol. 2011;31: 302-308.

79. Nieminen TH, Hagelberg NM, Saari TI, et al. Oxycodone concentrations are greatly increased by the concomitant use of ritonavir or lopinavir/ ritonavir. Eur J Clin Pharmacol. 2010;66:977-985.

80. Nieminen TH, Hagelberg NM, Saari TI, et al. Rifampin greatly reduces the plasma concentrations of intravenous and oral oxycodone. Anesthesiology. 2009;110:1371-1378.

81. Gronlund J, Saari T, Hagelberg N, et al. Effect of telithromycin on the pharmacokinetics and pharmacodynamics of oral oxycodone. J Clin Pharmacol. 2010;50:101-108.

82. Gronlund J, Saari TI, Hagelberg N, Neuvonen PJ, Olkkola KT, Laine K. Miconazole oral gel increases exposure to oral oxycodone by inhibition of CYP2D6 and CYP3A4. Antimicrob Agents Chemother. 2011;55:1063-1067.

83. Hagelberg NM, Nieminen TH, Saari TI, et al. Voriconazole drastically increases exposure to oral oxycodone. Eur J Clin Pharmacol. 2009;65:263-271.

84. Hagelberg NM, Nieminen TH, Saari TI, et al. Interaction of oxycodone and voriconazole - a case series of patients with cancer pain supports the findings of randomised controlled studies with healthy subjects. Eur J Clin Pharmacol. 2011;67:863-864.

85. Nieminen TH, Hagelberg NM, Saari TI, et al. St John's wort greatly reduces the concentrations of oral oxycodone. Eur J Pain. 2010;14:854-859.

86. Saari TI, Gronlund J, Hagelberg NM, et al. Effects of itraconazole on the pharmacokinetics and pharmacodynamics of intravenously and orally administered oxycodone. Eur J Clin Pharmacol. 2010;66:387-397.

87. Nieminen TH, Hagelberg NM, Saari TI, et al. Grapefruit juice enhances the exposure to oral oxycodone. Basic Clin Pharmacol Toxicol. 2010;107:782-788.

88. Lemberg KK, Siiskonen AO, Kontinen VK, Yli-Kauhaluoma JT, Kalso EA. Pharmacological characterization of noroxymorphone as a new opioid for spinal analgesia. Anesth Analg. 2008;106:463-470. 
89. Maddocks I, Somogyi A, Abbott F, Hayball P, Parker D. Attenuation of morphine-induced delirium in palliative care by substitution with infusion of oxycodone. J Pain Symptom Manage. 1996;12:182-189.

90. Heiskanen T, Olkkola KT, Kalso E. Effects of blocking CYP2D6 on the pharmacokinetics and pharmacodynamics of oxycodone. Clin Pharmacol Ther. 1998;64:603-611.

91. Susce MT, Murray-Carmichael E, de Leon J. Response to hydrocodone, codeine and oxycodone in a CYP2D6 poor metabolizer. Prog Neuropsychopharmacol Biol Psychiatry. 2006;30:1356-1358.

92. Samer CF, Daali Y, Wagner M, et al. Genetic polymorphisms and drug interactions modulating CYP2D6 and CYP3A activities have a major effect on oxycodone analgesic efficacy and safety. Br J Pharmacol. 2010;160:919-930.

93. Zwisler ST, Enggaard TP, Noehr-Jensen L, et al. The hypoalgesic effect of oxycodone in human experimental pain models in relation to the CYP2D6 oxidation polymorphism. Basic Clin Pharmacol Toxicol. 2009;104:335-344.

94. Zwisler ST, Enggaard TP, Mikkelsen S, Brosen K, Sindrup SH. Impact of the CYP2D6 genotype on post-operative intravenous oxycodone analgesia. Acta Anaesthesiol Scand. 2010;54:232-240.

95. Andreassen TN, Eftedal I, Klepstad P, et al. Do CYP2D6 genotypes reflect oxycodone requirements for cancer patients treated for cancer pain? A cross-sectional multicentre study. Eur J Clin Pharmacol. 2012;68:55-64.

96. Fareed A, Casarella J, Amar R, Vayalapalli S, Drexler K. Methadone maintenance dosing guideline for opioid dependence, a literature review. J Addict Dis. 2010;29:1-14.

97. Shaiova L, Berger A, Blinderman CD, et al. Consensus guideline on parenteral methadone use in pain and palliative care. Palliat Support Care. 2008;6:165-176.

98. Fredheim OM, Moksnes K, Borchgrevink PC, Kaasa S, Dale O. Clinical pharmacology of methadone for pain. Acta Anaesthesiol Scand. 2008;52:879-889.

99. Ansermot N, Albayrak O, Schlapfer J, et al. Substitution of (R,S)methadone by (R)-methadone: impact on QTe interval. Arch Intern Med. 2010;170:529-536.

100. Quigley C. Opioid switching to improve pain relief and drug tolerability. Cochrane Database Syst Rev. 2004;(3):CD004847.

101. Coller JK, Joergensen C, Foster DJ, et al. Lack of influence of CYP2D6 genotype on the clearance of (R)-, (S)-and racemic-methadone. Int J Clin Pharmacol Ther. 2007;45:410-417.

102. Crettol S, Deglon JJ, Besson J, et al. ABCB1 and cytochrome P450 genotypes and phenotypes: influence on methadone plasma levels and response to treatment. Clin Pharmacol Ther. 2006;80:668-681.

103. Fonseca F, de la Torre R, Diaz L, et al. Contribution of cytochrome $\mathrm{P} 450$ and $\mathrm{ABCB} 1$ genetic variability on methadone pharmacokinetics, dose requirements, and response. PloS One. 2011;6:e19527.

104. Shiran MR, Lennard MS, Iqbal MZ, et al. Contribution of the activities of CYP3A, CYP2D6, CYP1A2 and other potential covariates to the disposition of methadone in patients undergoing methadone maintenance treatment. Br J Clin Pharmacol. 2009;67:29-37.

105. Coller JK, Barratt DT, Dahlen K, Loennechen MH, Somogyi AA. $\mathrm{ABCB} 1$ genetic variability and methadone dosage requirements in opioid-dependent individuals. Clin Pharmacol Ther. 2006; 80:682-690.

106. Levran O, O"Hara K, Peles E, et al. ABCB1 (MDR1) genetic variants are associated with methadone doses required for effective treatment of heroin dependence. Hum Mol Genet. 2008;17:2219-2227.

107. Bunten H, Liang WJ, Pounder D, Seneviratne C, Osselton MD. CYP2B6 and OPRM1 gene variations predict methadone-related deaths. Addict Biol. 2011;16:142-144.

108. Bunten H, Liang WJ, Pounder DJ, Seneviratne C, Osselton D. OPRM1 and CYP2B6 gene variants as risk factors in methadone-related deaths. Clin Pharmacol Ther. 2010;88:383-389.

109. Levran O, Peles E, Hamon S, Randesi M, Adelson M, Kreek MJ. CYP2B6 SNPs are associated with methadone dose required for effective treatment of opioid addiction. Addict Biol. Epub July 25, 2011.
110. Wang SC, Ho IK, Tsou HH, et al. CYP2B6 polymorphisms influence the plasma concentration and clearance of the methadone S-enantiomer. J Clin Psychopharmacol. 2011;31:463-469.

111. Landau R, Cahana A, Smiley RM, Antonarakis SE, Blouin JL. Genetic variability of mu-opioid receptor in an obstetric population. Anesthesiology. 2004;100:1030-1033.

112. Tan EC, Tan CH, Karupathivan U, Yap EP. Mu opioid receptor gene polymorphisms and heroin dependence in Asian populations. Neuroreport. 2003;14:569-572.

113. Crowley JJ, Oslin DW, Patkar AA, et al. A genetic association study of the mu opioid receptor and severe opioid dependence. Psychiatr Genet. 2003;13:169-173.

114. Kroslak T, Laforge KS, Gianotti RJ, Ho A, Nielsen DA, Kreek MJ. The single nucleotide polymorphism A118G alters functional properties of the human mu opioid receptor. J Neurochem. 2007;103:77-87.

115. Bond C, LaForge KS, Tian M, et al. Single-nucleotide polymorphism in the human mu opioid receptor gene alters beta-endorphin binding and activity: possible implications for opiate addiction. Proc Natl Acad Sci U SA. 1998;95:9608-9613.

116. Zhang Y, Wang D, Johnson AD, Papp AC, Sadee W. Allelic expression imbalance of human mu opioid receptor (OPRM1) caused by variant A118G. J Biol Chem. 2005;280:32618-32624.

117. Beyer A, Koch T, Schroder H, Schulz S, Hollt V. Effect of the A118G polymorphism on binding affinity, potency and agonistmediated endocytosis, desensitization, and resensitization of the human mu-opioid receptor. $J$ Neurochem. 2004;89:553-560.

118. Oertel BG, Kettner M, Scholich K, et al. A common human microopioid receptor genetic variant diminishes the receptor signaling efficacy in brain regions processing the sensory information of pain. J Biol Chem. 2009;284:6530-6535.

119. Mahmoud S, Thorsell A, Sommer WH, et al. Pharmacological consequence of the A118G mu opioid receptor polymorphism on morphineand fentanyl-mediated modulation of $\mathrm{Ca}(2)$ channels in humanized mouse sensory neurons. Anesthesiology. 2011;115:1054-1062.

120. Fillingim RB, Kaplan L, Staud R, et al. The A118G single nucleotide polymorphism of the mu-opioid receptor gene (OPRM1) is associated with pressure pain sensitivity in humans. J Pain. 2005;6: $159-167$.

121. Huang CJ, Liu HF, Su NY, et al. Association between human opioid receptor genes polymorphisms and pressure pain sensitivity in females. Anaesthesia. 2008;63:1288-1295.

122. Vossen H, Kenis G, Rutten B, van Os J, Hermens H, Lousberg R. The genetic influence on the cortical processing of experimental pain and the moderating effect of pain status. PloS One. 2010;5:e13641.

123. Zwisler ST, Enggaard TP, Noehr-Jensen L, et al. The antinociceptive effect and adverse drug reactions of oxycodone in human experimental pain in relation to genetic variations in the OPRM1 and ABCB1 genes. Fundam Clin Pharmacol. 2010;24:517-524.

124. Landau R, Kern C, Columb MO, Smiley RM, Blouin JL. Genetic variability of the mu-opioid receptor influences intrathecal fentanyl analgesia requirements in laboring women. Pain. 2008;139:5-14.

125. Wong CA, McCarthy RJ, Blouin J, Landau R. Observational study of the effect of mu-opioid receptor genetic polymorphism on intrathecal opioid labor analgesia and post-cesarean delivery analgesia. Int J Obstet Anesth. 2010;19:246-253.

126. Camorcia M, Capogna G, Stirparo S, Berritta C, Blouin JL, Landau R. Effect of mu-opioid receptor A118G polymorphism on the ED50 of epidural sufentanil for labor analgesia. Int J Obstet Anesth. 2012;21:40-44.

127. Sia AT, Lim Y, Lim EC, et al. A118G single nucleotide polymorphism of human mu-opioid receptor gene influences pain perception and patient-controlled intravenous morphine consumption after intrathecal morphine for postcesarean analgesia. Anesthesiology. 2008;109:520-526.

128. Tan EC, Lim Y, Teo YY, Goh R, Law HY, Sia AT. Ethnic differences in pain perception and patient-controlled analgesia usage for postoperative pain. J Pain. 2008;9:849-855. 
129. Tan EC, Lim EC, Teo YY, Lim Y, Law HY, Sia AT. Ethnicity and OPRM variant independently predict pain perception and patient-controlled analgesia usage for post-operative pain. Mol Pain. 2009;5:32.

130. Landau R. One size does not fit all: genetic variability of mu-opioid receptor and postoperative morphine consumption. Anesthesiology. 2006;105:235-237.

131. Landau R, Ortner C, Carvalho B. Challenges in interpreting joined allelic combinations of OPRM1 and COMT genes. Anesth Analg. 2011;113:432.

132. Chou WY, Wang CH, Liu PH, Liu CC, Tseng CC, Jawan B. Human opioid receptor $\mathrm{A} 118 \mathrm{G}$ polymorphism affects intravenous patientcontrolled analgesia morphine consumption after total abdominal hysterectomy. Anesthesiology. 2006;105:334-337.

133. Chou WY, Yang LC, Lu HF, et al. Association of mu-opioid receptor gene polymorphism (A118G) with variations in morphine consumption for analgesia after total knee arthroplasty. Acta Anaesthesiol Scand. 2006;50:787-792.

134. Coulbault L, Beaussier M, Verstuyft C, et al. Environmental and genetic factors associated with morphine response in the postoperative period. Clin Pharmacol Ther. 2006;79:316-324.

135. Kolesnikov Y, Gabovits B, Levin A, Voiko E, Veske A. Combined catechol-O-methyltransferase and mu-opioid receptor gene polymorphisms affect morphine postoperative analgesia and central side effects. Anesth Analg. 2011;112:448-453.

136. Zhang W, Chang YZ, Kan QC, et al. Association of human micro-opioid receptor gene polymorphism $\mathrm{A} 118 \mathrm{G}$ with fentanyl analgesia consumption in Chinese gynaecological patients. Anaesthesia. 2010;65:130-135.

137. Fukuda K, Hayashida M, Ikeda K, Koukita Y, Ichinohe T, Kaneko Y. Diversity of opioid requirements for postoperative pain control following oral surgery - is it affected by polymorphism of the mu-opioid receptor? Anesth Prog. 2010;57:145-149.

138. Fukuda K, Hayashida M, Ide S, et al. Association between OPRM1 gene polymorphisms and fentanyl sensitivity in patients undergoing painful cosmetic surgery. Pain. 2009;147:194-201.

139. Wu WD, Wang Y, Fang YM, Zhou HY. Polymorphism of the micro-opioid receptor gene (OPRM1 $118 \mathrm{~A}>\mathrm{G}$ ) affects fentanylinduced analgesia during anesthesia and recovery. Mol Diagn Ther. 2009;13:331-337.

140. Zhang W, Yuan JJ, Kan QC, Zhang LR, Chang YZ, Wang ZY. Study of the OPRM1 A118G genetic polymorphism associated with postoperative nausea and vomiting induced by fentanyl intravenous analgesia. Minerva Anestesiol. 2011;77:33-39.

141. Ginosar Y, Davidson EM, Meroz Y, Blotnick S, Shacham M, Caraco Y. Mu-opioid receptor (A118G) single-nucleotide polymorphism affects alfentanil requirements for extracorporeal shock wave lithotripsy: a pharmacokinetic-pharmacodynamic study. Br JAnaesth . 2009; 103:420-427.

142. Klepstad P, Rakvag TT, Kaasa S, et al. The $118 \mathrm{~A}>$ G polymorphism in the human mu-opioid receptor gene may increase morphine requirements in patients with pain caused by malignant disease. Acta Anaesthesiol Scand. 2004;48:1232-1239.

143. Campa D, Gioia A, Tomei A, Poli P, Barale R. Association of $\mathrm{ABCB} 1 / \mathrm{MDR} 1$ and OPRM1 gene polymorphisms with morphine pain relief. Clin Pharmacol Ther. 2008;83:559-566.

144. Reyes-Gibby CC, Shete S, Rakvag T, et al. Exploring joint effects of genes and the clinical efficacy of morphine for cancer pain: OPRM1 and COMT gene. Pain. 2007;130:25-30.
145. Klepstad P, Fladvad T, Skorpen F, et al. Influence from genetic variability on opioid use for cancer pain: a European genetic association study of 2294 cancer pain patients. Pain. 2011;152:1139-1145.

146. Lotsch J, von Hentig N, Freynhagen R, et al. Cross-sectional analysis of the influence of currently known pharmacogenetic modulators on opioid therapy in outpatient pain centers. Pharmacogenet Genomics. 2009;19:429-436.

147. Belfer I, Segall S. COMT genetic variants and pain. Drugs Today (Barc). 2011;47:457-467.

148. Hickey OT, Nugent NF, Burke SM, Hafeez P, Mudrakouski AL, Shorten GD. Persistent pain after mastectomy with reconstruction. J Clin Anesth. 2011;23:482-488.

149. Jensen KB, Lonsdorf TB, Schalling M, Kosek E, Ingvar M. Increased sensitivity to thermal pain following a single opiate dose is influenced by the COMT val(158)met polymorphism. PloS One. 2009;4:e6016.

150. Stein DJ, Newman TK, Savitz J, Ramesar R. Warriors versus worriers: the role of COMT gene variants. CNS Spectr. 2006;11:745-748.

151. Diatchenko L, Nackley AG, Slade GD, et al. Catechol-O-methyltransferase gene polymorphisms are associated with multiple pain-evoking stimuli. Pain. 2006;125:216-224.

152. Zubieta JK, Heitzeg MM, Smith YR, et al. COMT val158 met genotype affects mu-opioid neurotransmitter responses to a pain stressor Science. 2003;299:1240-1243.

153. Andersen S, Skorpen F. Variation in the COMT gene: implications for pain perception and pain treatment. Pharmacogenomics. 2009;10: 669-684.

154. Nackley AG, Tan KS, Fecho K, Flood P, Diatchenko L, Maixner W. Catechol-O-methyltransferase inhibition increases pain sensitivity through activation of both beta2- and beta3-adrenergic receptors. Pain. 2007;128:199-208.

155. Tchivileva IE, Lim PF, Smith SB, et al. Effect of catechol-Omethyltransferase polymorphism on response to propranolol therapy in chronic musculoskeletal pain: a randomized, double-blind, placebo-controlled, crossover pilot study. Pharmacogenet Genomics. 2010;20:239-248.

156. Loggia ML, Jensen K, Gollub RL, Wasan AD, Edwards RR, Kong J. The catechol-O-methyltransferase (COMT) val158 met polymorphism affects brain responses to repeated painful stimuli. PloS One. 2011;6:e27764.

157. Walter C, Lotsch J. Meta-analysis of the relevance of the OPRM1 118A > G genetic variant for pain treatment. Pain. 2009;146: 270-275.

158. Kim H, Clark D, Dionne RA. Genetic contributions to clinical pain and analgesia: avoiding pitfalls in genetic research. $J$ Pain. 2009;10:663-693.

159. Kim H, Ramsay E, Lee H, Wahl S, Dionne RA. Genome-wide association study of acute post-surgical pain in humans. Pharmacogenomics. 2009; 10:171-179.

160. Wolfe D, Wechuck J, Krisky D, Mata M, Fink DJ. A clinical trial of gene therapy for chronic pain. Pain Med. 2009;10:1325-1330.

161. Glorioso JC, Fink DJ. Gene therapy for pain: introduction to the special issue. Gene Ther. 2009;16:453-454.

162. Fink DJ, Wechuck J, Mata M, et al. Gene therapy for pain: results of a phase I clinical trial. Ann Neurol. 2011;70:207-212.
Pharmacogenomics and Personalized Medicine

\section{Publish your work in this journal}

Pharmacogenomics and Personalized Medicine is an international, peerreviewed, open access journal characterizing the influence of genotype on pharmacology leading to the development of personalized treatment programs and individualized drug selection for improved safety, efficacy and sustainability. This journal is indexed on the American Chemical

\section{Dovepress}

Society's Chemical Abstracts Service (CAS). The manuscript management system is completely online and includes a very quick and fair peer-review system, which is all easy to use. Visit http://www.dovepress. $\mathrm{com} /$ testimonials.php to read real quotes from published authors. 